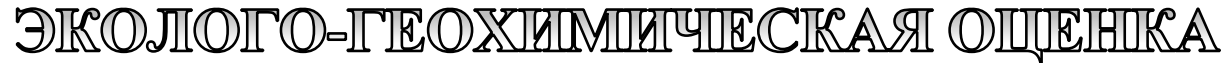

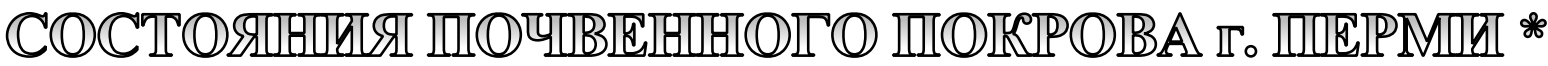

М.А. Шишкин, Институт экологии и генетики микроорганизмов УрО РАН

В.А. Гусев, Институт экологии и генетики микроорганизмов УрО РАН

Н.П. Шерстобитова, Институт экологии и генетики микроорганизмов УрО РАН

По результатам эколого-аналитических исследований проведена оценка степени химического загрязнения городских почв микроэлементами 1, 2 и 3-го классов опасности и органическими токсикантами. Выполнено картирование пространственной структуры экологического состояния почв жилой зоны г. Перми с выделением аномальных участков.

Ключевые слова: почва, химическое загрязнение, металлополлютанты, экотоксиканты, экологическое состояние, картирование.

\section{Введение}

Концентрирование в природных объектах химических веществ наиболее контрастно проявляется на урбанизированных территориях и характеризуется значительной глубиной воздействия на биогеоценозы и население. Особую озабоченность вызывает тот факт, что многие элементы и соединения переходят в высокоактивное рассеянное состояние и через механизмы переноса оседают на подстилающую поверхность, загрязняя объекты биогеоценоза и воздействуя на организм человека, что приводит к появлению специфической заболеваемости, ослаблению иммунных систем и росту болезней аллергического характера.

В 2016-2018 гг. было проведено комплексное обследование экологического состояния городских почв жилой зоны г. Перми по результатам химических и микробиологических исследований. В настоящей статье приведены результаты определения содержаний подвижных форм микроэлементов 1-го (кадмий, свинец, цинк), 2-го (медь, никель) и 3-го (марганец) классов опасности и идентификации органических экотоксикантов.

\section{Объекты и методы исследования}

Почва - основа городской экологической системы, в которой происходит взаимодействие воздушных и водных компонентов среды. На экологическое состояние почвенного покрова, отражающего как прошлые, так и настоящие процессы загрязнения, оказывают негативное воздействие производственные объекты и автотранспорт через выбросы загрязняющих веществ в атмосферный воздух.

Город Пермь - крупный индустриальный центр, и аэрогенное загрязнение почв является одним из наиболее распространенных почвенных нарушений. Жилая зона чередуется с территориями предприятий, парками, городскими лесами и занимает около $40 \%$ от общей площади города [8]. Суммарная площадь город-

* Статья подготовлена при финансовой поддержке гранта РФФИ «Эколого-аналитическая оценка загрязнения почвенного покрова г. Перми № 16-45-590497. 
ских зелёных насаждений достигает

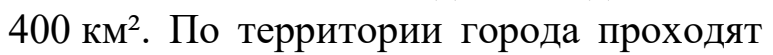
напряженные автомагистрали федерального значения и железные дороги.

Почвенный покров сформирован на элювиально-делювиальных тяжелых суглинках, породах пермской системы и древнем аллювии и представлен дерново-среднеподзолистыми тяжелосуглинистыми почвами, в долинах рек - дерновыми, дерново-глееватыми, аллювиальными и торфяно-болотными почвами [2]. На урбанизированных территориях выделяют естественные почвы, естественно-антропогенные поверхностно преобразованные почвы, антропогенные глубоко преобразованные урбаноземы и техногенные поверхностные почвоподобные образования $[1,7]$, и наиболее объективную картину изменений, происходящих в почве в результате антропогенеза, можно получить на участках с сохраненными зональными почвами.

Для выявления антропогенной нагрузки была проведена почвенная съемка с плотностью опробования одна пробная площадка на один км². Отбор проб проведен с глубины до 5 см на участках, где почвы в значительной мере сохранили свой генетический профиль [3]. Отобрано и проанализировано 214 городских почв на территориях районов: Орджоникидзевского (ОР), Мотовилихинского (МР), Ленинского (ЛР), Свердловского (СР), Дзержинского (ДР), Индустриального (ИР) и Кировского (КР). Контрольные образцы были взяты в 25-40 км западнее и юго-западнее г. Перми (с. Ласьва, д. Ольховка).

Содержание подвижных форм металлополлютантов определяли методом атомно-абсорбционной спектрометрии на спектрометре Shimadzu AA-6300 в пламени ацетилен-воздух, используя водную и кислотную вытяжки $[4,5]$. Обработку полученных данных проводили методами прикладной геохимии. Параметры загрязнения (коэффициенты накопления - Kс, суммарные показатели загрязнения - СПЗ) определяли по сравнению с их значениями в контрольной (фоновой) выборке [6].
В соответствии с ИСО 110704-4 фоновая концентрация - это средняя концентрация вещества в исследуемой почве, зависящая от геологических и почвообразующих условий, поэтому фоновыми (контрольными) массовыми долями химических элементов можно считать их концентрации в почвах ландшафтов, не подвергающихся импактному техногенному воздействию, удаленных примерно на 15 км и более от источника выбросов.

Идентификацию органических соединений проводили методом ГХ-МС с использованием хромато-масс-спектрометрической системы «Agilent $6890 / 5973 \mathrm{~N}$ ». Для извлечения органических соединений из почв использовали жидкостную экстракцию хлороформом на аппарате Сокслета. Разделение органических примесей, присутствующих в экстрактах, проводили на капиллярной колонке HP-5MS 30м х 0,25мм х 0,25мкм) при программировании температуры. Полученные хроматограммы обрабатывали с помощью автоматизированной системы обработки масс-спектральных данных AMDIS c поиском целевых компонентов по данным библиотеки Американского Агентства окружающей среды NIST05/NISTEPA.MSL с фактором сходства не менее $80 \%$.

\section{Результаты и их обсуждение}

Содержание кислоторастворимых форм металлополлютантов в исследованных почвенных образцах приведено в табл. 1, из которой следует, что токсичные металлы обнаружены в большинстве исследованных образцов. Накопление $\mathrm{Cd}, \mathrm{Pb}, \mathrm{Zn}, \mathrm{Cu}$ и $\mathrm{Ni}(K c>1,5)$ отмечено в 53-89\% изученных образцов почв Ленинского района. На территории Дзержинского и Индустриального района массовые доли $\mathrm{Pb}, \mathrm{Zn}, \mathrm{Cu}$ и $\mathrm{Ni}$ выше контроля в 52-78\% проб. В Кировском районе зафиксировано накопление $\mathrm{Pb}(93 \%)$ $\mathrm{Zn}(61 \%)$ и $\mathrm{Cu}(64 \%)$. В городских образцах накопление $\mathrm{Mn}$ выявлено в единичных случаях. Установлено, что на загряз- 
Содержание кислоторастворимых форм металлов (мг/кг) в почвах по районам г. Перми и в контроле

\begin{tabular}{|c|c|c|c|c|c|c|c|}
\hline $\begin{array}{c}\text { Районы } \\
\text { (площадки) }\end{array}$ & Показатели & $\mathrm{Cd}$ & $\mathrm{Pb}$ & $\mathrm{Zn}$ & $\mathrm{Cu}$ & $\mathrm{Ni}$ & $\mathrm{Mn}$ \\
\hline \multirow{3}{*}{$\mathrm{OP}(56)$} & Встречаемость, \% & 100 & 98 & 98 & 96 & 100 & 100 \\
\hline & $\begin{array}{l}\text { Минимум- } \\
\text { максимум } \\
\text { среднее }\end{array}$ & $\frac{0,03-1,4}{0,32}$ & $\frac{6,4-47,9}{19,4}$ & $\frac{26,5-79,4}{54,5}$ & $\frac{8,1-72,5}{20,1}$ & $\frac{6,9-47,3}{19,2}$ & $\frac{26,6-603,2}{297,9}$ \\
\hline & $\begin{array}{c}K c>1,5 / K c>3 \\
\%\end{array}$ & $27 / 7$ & $34 / 21$ & $14 / 0$ & $29 / 19$ & $13 / 0$ & $2 / 0$ \\
\hline \multirow{3}{*}{ MP (38) } & Встречаемость, \% & 100 & 92 & 97 & 97 & 100 & 100 \\
\hline & $\begin{array}{l}\text { Минимум- } \\
\text { максимум } \\
\text { среднее }\end{array}$ & $\frac{0,06-1,3}{0,34}$ & $\frac{7,5-77,0}{21,7}$ & $\frac{27,9-177,3}{65,4}$ & $\frac{9,7-59,9}{25,7}$ & $\frac{9,5-44,2}{24,3}$ & $\frac{72,9-565,9}{281}$ \\
\hline & $\begin{array}{c}K c>1,5 / K c>3 \\
\%\end{array}$ & $47 / 25$ & $18 / 33$ & $21 / 14$ & $63 / 25$ & $11 / 1$ & 0 \\
\hline \multirow{3}{*}{ ЛP (19) } & Встречаемость, \% & 100 & 95 & 89 & 95 & 100 & 100 \\
\hline & $\begin{array}{l}\text { Минимум- } \\
\text { максимум } \\
\text { среднее }\end{array}$ & $\frac{0,18-1,4}{0,6}$ & $\frac{13,1-101}{46,7}$ & $\frac{28-293,5}{65,4}$ & $\frac{7,1-60,6}{29}$ & $\frac{11,6-80,7}{31,2}$ & $\frac{72,9-565,9}{281}$ \\
\hline & $\begin{array}{c}K c>1,5 / K c>3 \\
\%\end{array}$ & $74 / 50$ & $89 / 71$ & $63 / 75$ & $74 / 43$ & $53 / 20$ & 0 \\
\hline \multirow{3}{*}{$\mathrm{CP}(25)$} & Встречаемость, \% & 100 & 96 & 100 & 100 & 100 & 100 \\
\hline & $\begin{array}{l}\text { Минимум- } \\
\text { максимум } \\
\text { среднее }\end{array}$ & $\frac{0,15-1,0}{0,44}$ & $\frac{12,6-85,3}{30}$ & $\frac{46,8-224,1}{103,4}$ & $\frac{13,7-44,2}{26}$ & $\frac{23-113,7}{45}$ & $\frac{179,5-747,4}{324}$ \\
\hline & $\begin{array}{c}K c>1,5 / K c>3 \\
\%\end{array}$ & $28 / 0$ & $52 / 34$ & $48 / 8$ & $48 / 0$ & $32 / 0$ & 0 \\
\hline \multirow{3}{*}{ ДР (23) } & Встречаемость, \% & 100 & 100 & 100 & 100 & 100 & 100 \\
\hline & $\begin{array}{l}\text { Минимум- } \\
\text { максимум } \\
\text { среднее }\end{array}$ & $\frac{0,09-0,83}{0,33}$ & $\frac{8,3-112,9}{40}$ & $\frac{19,3-240,7}{107,8}$ & $\frac{10,6-125,7}{31,5}$ & $\frac{8-112,1}{36,1}$ & $\frac{149,5-547,8}{304}$ \\
\hline & $\begin{array}{c}K c>1,5 / K c>3 \\
\%\end{array}$ & $43 / 30$ & $78 / 61$ & $61 / 50$ & $78 / 39$ & $52 / 42$ & $4 / 0$ \\
\hline \multirow{3}{*}{ ИР (24) } & Встречаемость, \% & 100 & 100 & 100 & 100 & 100 & 100 \\
\hline & $\begin{array}{l}\text { Минимум- } \\
\text { максимум } \\
\text { среднее }\end{array}$ & $\frac{0,15-1,5}{0,4}$ & $\frac{11,2-98,3}{30}$ & $\frac{25,8-210,6}{105,7}$ & $\frac{7,7-37,7}{23,4}$ & $\frac{12,23-104,6}{41,2}$ & $\frac{148,5-735,4}{401,5}$ \\
\hline & $\begin{array}{c}K c>1,5 / K c>3 \\
\%\end{array}$ & $45 / 30$ & $73 / 19$ & $64 / 21$ & $59 / 15$ & $64 / 21$ & $5 / 100$ \\
\hline \multirow{3}{*}{$\mathrm{KP}(28)$} & Встречаемость, \% & 100 & 96 & 100 & 100 & 100 & 100 \\
\hline & $\begin{array}{l}\text { Минимум- } \\
\text { максимум } \\
\text { среднее }\end{array}$ & $\frac{0,06-0,5}{0,24}$ & $\frac{8,1-103,5}{29,8}$ & $\frac{12,8-152,6}{69,3}$ & $\frac{5,9-24,3}{13,8}$ & $\frac{4,1-55,6}{16,6}$ & $\frac{73,8-655,4}{272,2}$ \\
\hline & $\begin{array}{c}K c>1,5 / K c>3 \\
\%\end{array}$ & $36 / 0$ & $93 / 69$ & $61 / 29$ & $64 / 0$ & $29 / 13$ & $7 / 0$ \\
\hline \multicolumn{2}{|c|}{ Контроль (с. Ласьва) } & 0,18 & 6,51 & 35,85 & 8,66 & 12,23 & 357,48 \\
\hline \multicolumn{2}{|c|}{ Контроль (с. Ольховка) } & 0,36 & 17,19 & 66,15 & 16,68 & 29,96 & 973,82 \\
\hline
\end{tabular}

ненных площадках высока доля проб с коэффициентами накопления на уровне 3 с с и выше по содержанию свинца в Ленинском (71\%), Кировском (69\%) и Дзержинском (61\%), по содержанию цинка - в Ленинском (75\%) и Дзержинском (50\%) районах. Следует отметить, что на половине загрязненных $\mathrm{Cd}$ пло- 
щадок Ленинского района его массовые доли превышают контрольные в 3 и более раза. Коэффициенты накопления марганца в Индустриальном районе на всех 5\% загрязненных площадок более трех (см. табл. 1).

По средним значениям коэффициентов накопления выявлены ассоциации микроэлементов: накапливающиеся $(K c \geq 1,5)$, близкие к контролю $(K c<1,5>1)$ и ниже контроля $(K c<1,0)$ (табл. 2). В группе накапливающихся и превышающих контрольные содержания преобладают микроэлементы 1-го и 2-го классов опасности $(\mathrm{Pb}, \mathrm{Zn}, \mathrm{Ni} \mathrm{Cu}$ и реже $\mathrm{Cd}$ ). По отношению к контролю дефицитными являются содержания марганца. Больше всего накапливающихся металополлютантов выявлено в почвенных образцах Ленинского района, минимум - на площадках Орджоникидзевского района (см. табл. 2).

Значения СПЗ кислоторастворимыми формами металлов изменяются от 1 до 44, при среднем значении 6.

Пространственное распределение показателя СПЗ показано на рис. 1, из которого видно, что на большинстве обследованных площадок значения $Z c$ не превышают среднее по городу, причем на 53 из них загрязнения металлополлютантами вообще не выявлено. Однако на $30 \%$ пробных площадок установлены повышенные (выше среднего + стандарт) и аномальные значения (выше среднего +2 стандарта) значения показателя СПЗ.
Аномальный уровень загрязнения металлополлютантами обнаружен в Ленинском (9 площадок), Дзержинском (8 площадок), Индустриальном (2 площадки) и Кировском (2 площадки) районах (см. рис.). Максимальное значение $\mathrm{Zc}=44$ зафиксировано на площадке №77 (Дзержинский район).

Результаты определения массовых долей водорастворимых форм микроэлементов в водных вытяжках по районам г. Перми приведены в табл. 2. Во всех исследованных образцах обнаружен $\mathrm{Zn}, \mathrm{Cu}$, $\mathrm{Ni}$ и Mn. В большинстве водных вытяжек образцов почв выявлен $\mathrm{Cd}$ (63-88\%), и только в пробах Кировского района его встречаемость составила 18\%. Свинец в целом по городу обнаружен в $65 \%$ исследованных образцов с максимальной встречаемостью (95\%) на площадках Индустриального района при минимуме $(8 \%)$ в образцах из Свердловского района (см. табл. 2). Среди накапливающихся $\mathrm{Pb}, \mathrm{Cu}$ и $\mathrm{Ni}$ значения $K c>3$ выявлены на площадках Ленинского (100-84\%) и Дзержинского (59-78\%) районов. Значения $K c>3$ установлены для $\mathrm{Cd}$ $(78 \%)$ и $\mathrm{Cu}(88 \%)$ в образцах из Свердловского района. Максимальное число проб выше контроля в 3 и более раза обнаружено для кадмия на площадках Индустриального района (см. табл. 2).

Из табл. 3, в которой приведены ассоциации водорастворимых форм микроэлементов, следует, что в большинстве районов в группе накапливающихся так-

Таблийа 2

\section{Геохимические ассоциации кислоторастворимых} форм металлов в почвах по районам г. Перми

\begin{tabular}{|c|c|c|c|}
\hline $\begin{array}{c}\text { Районы } \\
\text { (площадки) }\end{array}$ & Накапливающиеся & Близкие к контролю & Ниже контроля \\
\hline $\mathrm{OP}(56)$ & $\mathrm{Pb}_{1,5}$ & $\mathrm{Cu}_{1,4}>\mathrm{Cd}_{1,1}$ & $\mathrm{Zn}_{1,0}>\mathrm{Ni}_{0,8}>\mathrm{Mn}_{0,5}$ \\
\hline $\mathrm{MP}(38)$ & $\mathrm{Cu}_{1,9}>\mathrm{Pb}_{1,7}$ & $(\mathrm{Cd}, \mathrm{Zn})_{1,2}$ & $\mathrm{Ni}_{1,0}>\mathrm{Mn}_{0,4}$ \\
\hline $\mathrm{JP}(19)$ & $\mathrm{Pb}_{5,4}>\mathrm{Zn}_{2,8}>\mathrm{Cu}_{2,6}>\mathrm{Cd}_{2,5}>\mathrm{Ni}_{1,9}>\mathrm{Mn}_{1,5}$ & - & - \\
\hline $\mathrm{CP}(25)$ & $\mathrm{Pb}_{1,7}>\left(\mathrm{Zn}_{1} \mathrm{Cu}, \mathrm{Ni}_{1,5}\right.$ & $\mathrm{Cd}_{1,2}$ & $\mathrm{Mn}_{0,4}$ \\
\hline $\mathrm{ZP}(23)$ & $\mathrm{Pb}_{4,5}>\mathrm{Cu}_{3,2}>\mathrm{Zn}_{2,3}>\mathrm{Ni}_{2,1}$ & $\mathrm{Cd}_{1,4}$ & $\mathrm{Mn}_{0,6}$ \\
\hline $\mathrm{UP}(24)$ & $\mathrm{Pb}_{2,7}>\mathrm{Ni}_{2,2}>\mathrm{Zn}_{2,1}>\mathrm{Cu}_{1,9}>\mathrm{Cd}_{1,5}$ & - & $\mathrm{Mn}_{0,7}$ \\
\hline $\mathrm{KP}(28)$ & $\mathrm{Pb}_{4,4}>\mathrm{Zn}_{2,0}>\mathrm{Cu}_{1,6}$ & $\mathrm{Ni}_{1,4}>\mathrm{Cd}_{1,3}$ & $\mathrm{Mn}_{0,7}$ \\
\hline
\end{tabular}




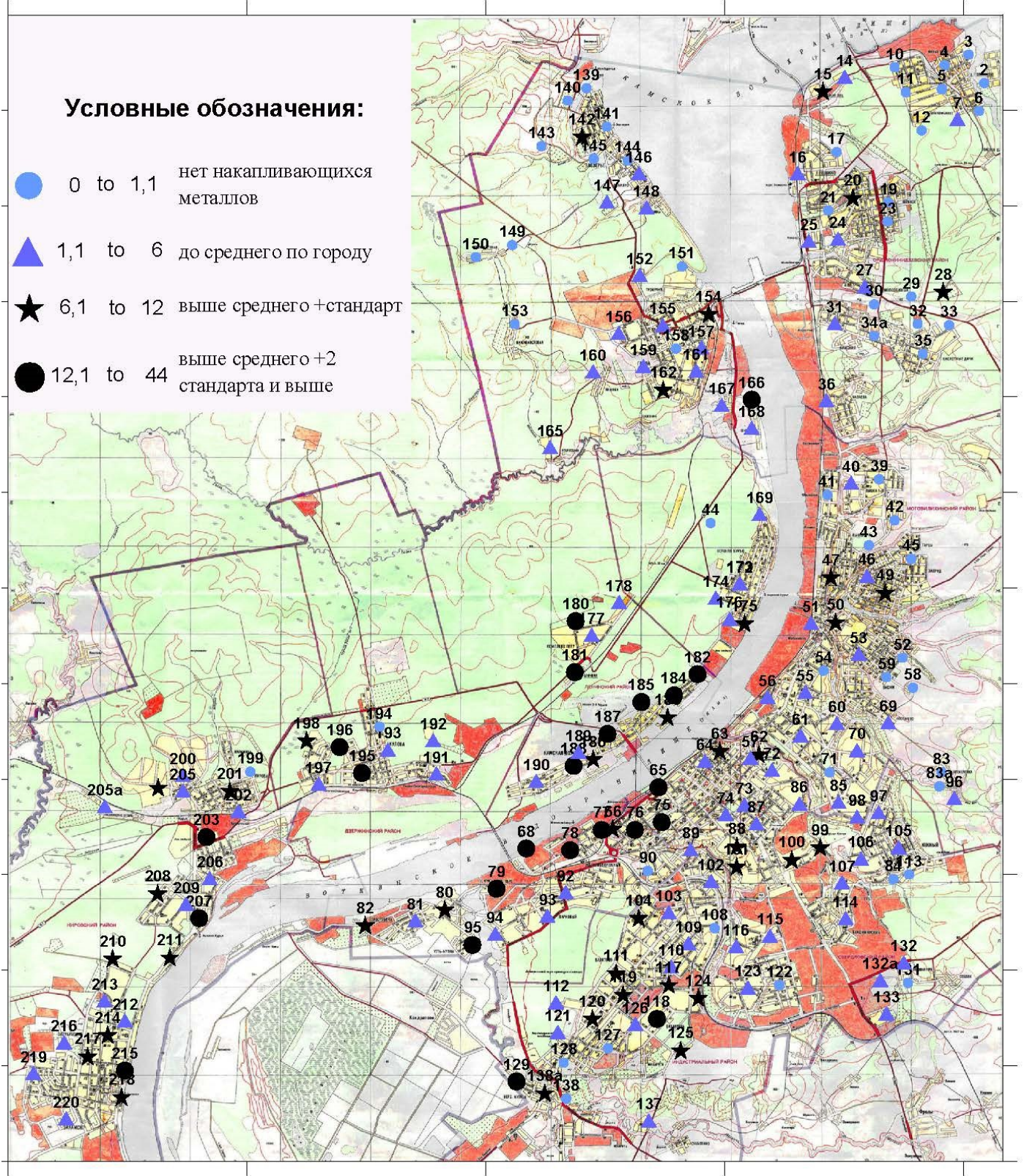

Рис. 1. Карта распределения значений СПЗ кислоторастворимых форм металлов в почвах жилой зоны г. Перми

же обнаружены опасные металополлютанты (Pb Ni, Cu, Cd). При этом массовые содержания водорастворимого $\mathrm{Zn}$, в большинстве случаев, ниже контроля (см. табл. 4).

Значения суммарного показателя загрязнения СПЗ в водных вытяжках составили 1 - 41 при среднем значении 8. Распределение значений СПЗ по водорастворимым формам металлов на обследованной территории приведено на рис. 2. Как следует из рис. 2 , в большинстве $(57 \%)$ случаев значения суммарного показателя загрязнения не превысили среднее по городу, а на 4 площадках Орджоникидзевского района СП $\leq 1$. Повышенные уровни загрязнения (СПЗ выше среднего по городу + стандарт) зафиксированы на 30\% пробных площадок. Самое большое число площадок с аномальным загрязнением (СПЗ выше среднего по городу + два стандарта) выявлено в Ленинском районе (13 площадок); далее следуют Кировский (5 площадок), Индустри- 


\section{Содержание водорастворимых форм металлов (мг/л) в почвах по районам г. Перми и в контроле}

\begin{tabular}{|c|c|c|c|c|c|c|c|}
\hline $\begin{array}{c}\text { Районы } \\
\text { (площадки) }\end{array}$ & Показатели & $\mathrm{Cd}$ & $\mathrm{Pb}$ & $\mathrm{Zn}$ & $\mathrm{Cu}$ & $\mathrm{Ni}$ & $\mathrm{Mn}$ \\
\hline \multirow{3}{*}{$\mathrm{OP}(56)$} & Встречаемость, \% & 73 & 80 & 100 & 100 & 100 & 100 \\
\hline & $\frac{\text { Минимум-максимум }}{\text { среднее }}$ & $\frac{0,001-0,3}{0,01}$ & $\frac{0,1-0,64}{0,34}$ & $\frac{0,08-0,75}{0,29}$ & $\frac{0,11-1,66}{0,30}$ & $\frac{0,66-0,4}{0,2}$ & $\frac{0,04-2,25}{0,79}$ \\
\hline & $K c>1,5 / K c>3 \%$ & $29 / 0$ & $64 / 28$ & $14 / 13$ & $66 / 27$ & $54 / 33$ & $9 / 20$ \\
\hline \multirow{3}{*}{ MP(38) } & Встречаемость, \% & 63 & 79 & 100 & 100 & 100 & 100 \\
\hline & $\begin{array}{c}\text { Минимум-максимум } \\
\text { среднее }\end{array}$ & $\frac{0,003-0,03}{0,02}$ & $\frac{0,05-0,6}{0,28}$ & $\frac{0,05-0,36}{0,17}$ & $\frac{0,11-1,1}{0,39}$ & $\frac{0,09-0,5}{0,3}$ & $\frac{0,07-2,0}{0,51}$ \\
\hline & $K c>1,5 / K c>3 \%$ & $54 / 15$ & $53 / 13$ & $3 / 0$ & $87 / 45$ & $82 / 35$ & 0 \\
\hline \multirow{3}{*}{$\pi P(19)$} & Встречаемость, \% & 89 & 58 & 100 & 100 & 100 & 100 \\
\hline & $\begin{array}{c}\text { Минимум-максимум } \\
\text { среднее }\end{array}$ & $\frac{0,01-0,06}{0,04}$ & $\frac{0,05-0,7}{0,38}$ & $\frac{0,07-0,7}{0,27}$ & $\frac{0,28-1,5}{0,68}$ & $\frac{0,14-1,17}{0,61}$ & $\frac{0,17-6,15}{1,0}$ \\
\hline & $K c>1,5 / K c>3 \%$ & $71 / 42$ & $82 / 100$ & $11 / 50$ & $100 / 95$ & $100 / 84$ & $11 / 0$ \\
\hline \multirow{3}{*}{$\mathrm{CP}(25)$} & Встречаемость, \% & 88 & 8 & 100 & 100 & 100 & 100 \\
\hline & $\frac{\text { Минимум-максимум }}{\text { среднее }}$ & $\frac{0,004-0,06}{0,03}$ & $\frac{0,11-0,32}{0,22}$ & $\frac{0,12-0,4}{0,22}$ & $\frac{0,31-1,03}{0,68}$ & $\frac{0,17-0,67}{0,33}$ & $\frac{0,26-0,96}{0,52}$ \\
\hline & $K c>1,5 / K c>3 \%$ & $82 / 78$ & 0 & 0 & $100 / 88$ & $96 / 25$ & 0 \\
\hline \multirow{3}{*}{ ДР (23) } & Встречаемость, \% & 67 & 83 & 100 & 100 & 100 & 100 \\
\hline & $\begin{array}{c}\text { Минимум-максимум } \\
\text { среднее }\end{array}$ & $\frac{0,005-0,05}{0,03}$ & $\frac{0,05-0,6}{0,25}$ & $\frac{0,08-0,25}{0,17}$ & $\frac{0,12-0,75}{0,33}$ & $\frac{0,07-0,3}{0,21}$ & $\frac{0,19-1,03}{0,46}$ \\
\hline & $K c>1,5 / K c>3 \%$ & $31 / 0$ & $85 / 59$ & 0 & $88 / 67$ & 9678 & 0 \\
\hline \multirow{3}{*}{ UP(24) } & Встречаемость, \% & 86 & 95 & 100 & 100 & 100 & 100 \\
\hline & $\frac{\text { Минимум-максимум }}{\text { среднее }}$ & $\frac{0,012-0,04}{0,03}$ & $\frac{0,22-0,7}{0,42}$ & $\frac{0,07-0,3}{0,17}$ & $\frac{0,05-0,58}{0,24}$ & $\frac{0,09-0,43}{0,32}$ & $\frac{0,12-3,3}{0,45}$ \\
\hline & $K c>1,5 / K c>3 \%$ & $47 / 100$ & $76 / 69$ & 0 & $64 / 29$ & $95 / 52$ & 0 \\
\hline \multirow{3}{*}{ KP (28) } & Встречаемость, \% & 18 & 54 & 100 & 100 & 100 & 100 \\
\hline & $\begin{array}{c}\text { Минимум-максимум } \\
\text { среднее }\end{array}$ & $\frac{0,002-0,01}{0,01}$ & $\frac{0,05-0,41}{0,29}$ & $\frac{0,06-0,86}{0,19}$ & $\frac{0,05-0,78}{0,3}$ & $\frac{0,05-0,43}{0,18}$ & $\frac{0,22-2,23}{0,7}$ \\
\hline & $K c>1,5 / K c>3 \%$ & 0 & $87 / 85$ & $11 / 33$ & $75 / 38$ & $86 / 46$ & $11 / 33$ \\
\hline \multicolumn{2}{|c|}{ Контроль (с.Ласьва) } & 0,02 & 0,8 & 0,22 & 0,09 & 0,06 & 0,74 \\
\hline \multicolumn{2}{|c|}{ Контроль (с.Ольховка) } & 0,009 & 0,22 & 0,39 & 0,15 & 0,13 & 3,15 \\
\hline
\end{tabular}

Геохимические ассоциации водорастворимых форм металлов в почвах по районам г. Перми

\begin{tabular}{|c|c|c|c|}
\hline $\begin{array}{c}\text { Районы } \\
\text { (площадки) }\end{array}$ & Накапливающиеся & Близкие к контролю & Ниже контроля \\
\hline $\mathrm{OP}(56)$ & $\mathrm{Cu}_{2,2}>\mathrm{Pb}_{2,1}>\mathrm{Ni}_{1,9}$ & $\mathrm{Cd}_{1,3}$ & $\mathrm{Zn}_{0,6}>\mathrm{Mn}_{0,5}$ \\
\hline $\mathrm{MP}(38)$ & $\mathrm{Ni}_{3,2}>\mathrm{Cu}_{3,1}>\mathrm{Pb}_{1,7}>\mathrm{Cd}_{1,6}$ & - & $\mathrm{Zn}_{0,6}>\mathrm{Mn}_{0,3}$ \\
\hline $\mathrm{MP}(19)$ & $\mathrm{Ni}_{8,4}>\mathrm{Cu}_{6,1}>\mathrm{Pb}_{3,8}>\mathrm{Cd}_{2,6}$ & $\mathrm{Zn}_{1,0}$ & $\mathrm{Mn}_{0,8}$ \\
\hline $\mathrm{CP}(25)$ & $\mathrm{Cu}_{4,5}>\mathrm{Cd}_{3,7}>\mathrm{Ni}_{2,5}$ & $\mathrm{~Pb}_{1,0}$ & $\mathrm{Zn}_{0,6}>\mathrm{Mn}_{0,2}$ \\
\hline $\mathrm{AP}(23)$ & $\mathrm{Cu}_{3,6}>\mathrm{Ni}_{3,5}>\mathrm{Pb}_{3,2}$ & $\mathrm{Cd}_{1,0}$ & $\mathrm{Zn}_{0,7}>\mathrm{Mn}_{0,6}$ \\
\hline $\mathrm{MP}(24)$ & $\mathrm{Ni}_{3,9}>\mathrm{Pb}_{3,7}>\mathrm{Cd}_{2,3}>\mathrm{Cu}_{2,0}>$ & - & $\mathrm{Zn}_{0,6}>\mathrm{Mn}_{0,7}$ \\
\hline $\mathrm{KP}(28)$ & $\mathrm{Pb}_{3,4}>\mathrm{Cu}_{3,3}>\mathrm{Ni}_{3,1}$ & - & $(\mathrm{Zn}, \mathrm{Mn}) 0,9>\mathrm{Cd}_{0,2}$ \\
\hline
\end{tabular}




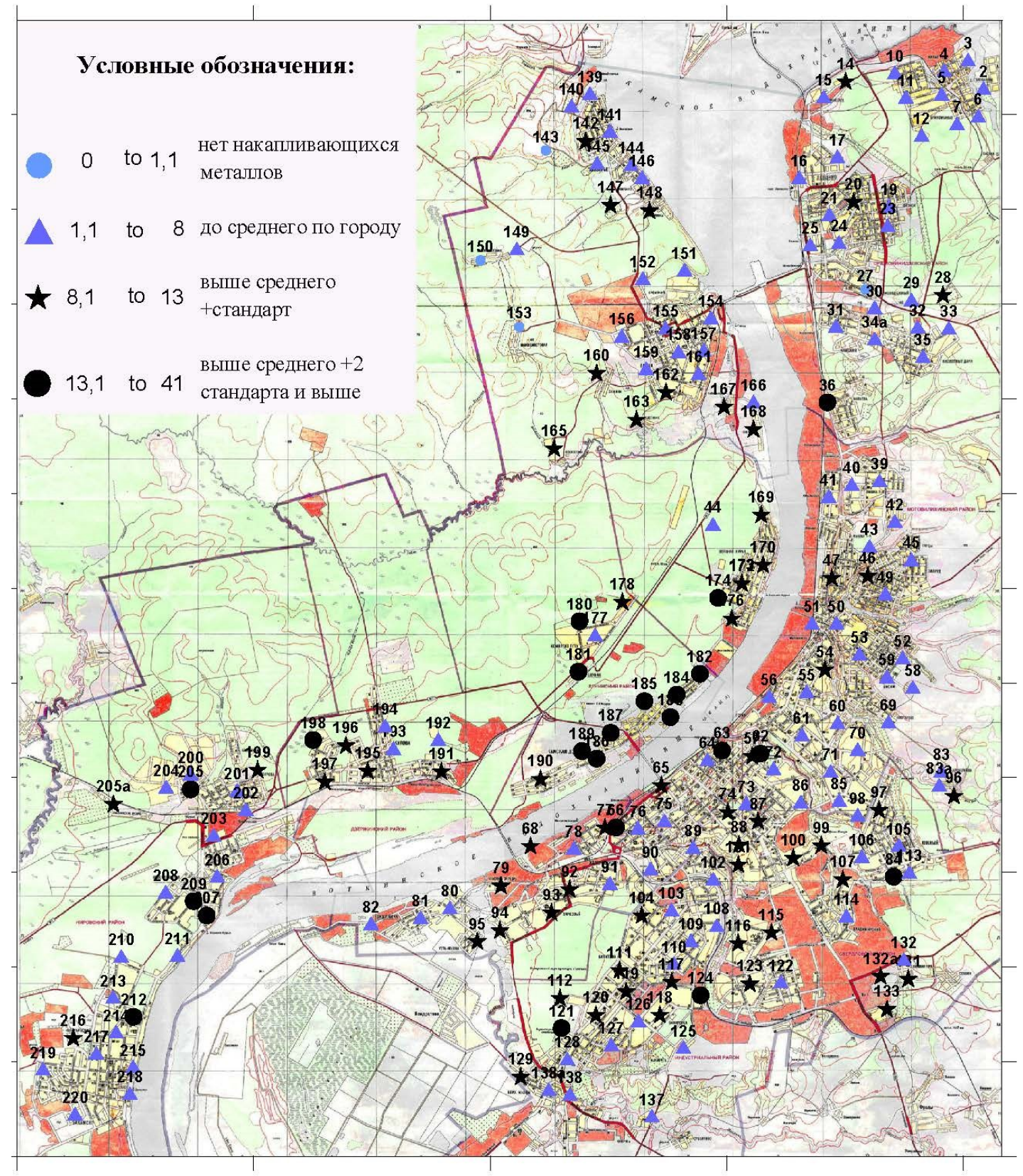

Рис. 2. Карта распределения значений СПЗ металлополлютантами водяной вытяжки почв жилой зоны г. Перми

альный (3 площадки) и Дзержинский (1 площадка) районы. Максимальное значение СПЗ = 41 установлено на площадке 188 в Ленинском районе (см. рис. 2).

Количество обнаруженных и идентифицированных органических экотоксикантов показано в табл. 5. Больше всего органических соединений в городских почвах в среднем выявлено на территории Кировского, Индустриального, Свердловского и Ленинского районов при минимуме в Дзержинском районе. Сред- нее количество идентифицированных органических экотоксикантов изменяется от 50 (Дзержинский район) до 60 (Индустриальный район). В контроле обнаружено 936 соединений, из которых идентифицировано 60 (см. табл. 5).

В спектре идентифицированных органических соединений в городских образцах преобладали углеводороды и кислородсодержащие соединения. Относительная доля алканов составляла от $17 \%$ (Индустриальный район) до $33 \%$ (Ленин- 
Количество органических экотоксикантов в почвах жилой зоны г. Перми и в контроле

\begin{tabular}{|c|c|c|c|c|}
\hline $\begin{array}{l}\text { Районы (число } \\
\text { площадок) }\end{array}$ & Органические соединения & Минимум & Максимум & Среднее \\
\hline \multirow{2}{*}{$\mathrm{OP}(56)$} & Всего обнаружено & 386 & 1042 & 672 \\
\hline & идентифицировано & 43 & 88 & 56 \\
\hline \multirow{2}{*}{ MP (38) } & Всего обнаружено & 507 & 1033 & 688 \\
\hline & идентифицировано & 48 & 91 & 59 \\
\hline \multirow{2}{*}{ ЛР (19) } & Всего обнаружено & 369 & 854 & 638 \\
\hline & идентифицировано & 31 & 76 & 52 \\
\hline \multirow{2}{*}{$\mathrm{CP}(25)$} & Всего обнаружено & 343 & 959 & 715 \\
\hline & идентифицировано & 37 & 73 & 51 \\
\hline \multirow{2}{*}{ ДР (24) } & Всего обнаружено & 196 & 749 & 599 \\
\hline & идентиффицировано & 27 & 64 & 50 \\
\hline \multirow{2}{*}{ ИР (24) } & Всего обнаружено & 583 & 1240 & 745 \\
\hline & идентифицировано & 48 & 87 & 60 \\
\hline \multirow{2}{*}{ KP (28) } & Всего обнаружено & 550 & 1350 & 771 \\
\hline & идентифицировано & 45 & 66 & 58 \\
\hline \multirow{2}{*}{ Контроль } & \multicolumn{3}{|l|}{ Всего обнаружено } & 936 \\
\hline & \multicolumn{3}{|l|}{ Идентифицировано } & 60 \\
\hline
\end{tabular}

ский район). Относительное содержание ароматических углеводородов колеблется в пределах от $17 \%$ (Орджоникидзевский район) до 27\% (Свердловский район). На долю ПАУ пришлось 30-39\% в образцах почв Кировского, Мотовилихинского, Орджоникидзевского и Индустриального районов. В пробах Свердловского и Дзержинского районов их доля составила - 19\%,а на площадках Ленинского района $-5 \%$. Относительная доля кислородсодержащих соединений в большинстве исследованных образцов не выше 21-32\%, и только в Кировском районе - 15\%.

Гораздо реже обнаружены производные алканов (до 4\%), циклоалканы (до $2 \%$ ), азотсодержащие, серосодержащие, фосфорсодержащие (до 1,5\%) и хлорорганические соединения (1-8\%). При этом следует отметить, что наибольшая доля хлорированной органики выявлена в пробах почвы Кировского района.

В контрольных образцах спектр идентифицированных экотоксикантов включал предельные углеводороды (относительная доля $32 \%$ ), кислородсодержащие соединения (относительная доля 30\%), ароматические углеводороды (относительная доля
$22 \%$ ). Однако в контроле значительно меньше выявлено полициклической ароматики (относительная доля 6\%). При этом следует отметить, что на контрольных площадках идентифицированы природные углеводороды растительного происхождения - терпены, с относительной долей $6 \%$. В контроле обнаружен и хлорсодержащий пестицид p,p'-DDE.

Из идентифицированных экотоксикантов наиболее экологически опасными являются ПАУ, ХОС, фталаты и ДДТ, входящие в список стойких органических загрязнителей (СО3). По классификации МАИР из группы 2В канцерогены, в исследованных образцах присутствуют Bis(2-ethylhexyl) phthalate, Dibutyl phthalate, Diethyl Phthalate, Naphthalene Benzo[k]fluoranthene, Carbazole, Ethane, hexachloro-, Ethylbenzene; из вероятно канцерогенных для человека (группа 2A) $o, p^{\prime}-D T, p, p^{\prime}-D D T, p, p^{\prime}-D D E$.

\section{Заключение}

По результатам проведенных химикоаналитических исследований дана характеристика состояния городских почв по 
содержанию в них подвижных форм токсичных микроэлементов первого $(\mathrm{Cd}, \mathrm{Pb}$, $\mathrm{Zn})$, второго $(\mathrm{Cu}, \mathrm{Ni})$ и третьего $(\mathrm{Mn})$ классов опасности, а также проведена идентификация органических экотоксикантов.

Как и следовало ожидать, содержания большинства обнаруженных металлополлютантов в образцах городской почвы оказались выше контрольных значений. Ассоциации накапливающихся и близких к контролю подвижных форм микроэлементов в целом близки, однако значения $K c$ металлов в водных вытяжках характеризуются большей контрастностью. Выявленные в городских образцах содержания марганца в большинстве случаев являются дефицитными. Больше всего площадок, аномально загрязненных металлополлютантами, установлено в Ленинском Дзержинском районах. По большинству идентифицированных органических экотоксикантов сущест- венного отличия между городскими почвами и контролем не установлено. Однако в контрольных образцах присутствует значительно меньше полициклической ароматики, а также обнаружены природные углеводороды растительного происхождения (терпены) и пестициды.

Выполненное обследование позволило выявить реальное экологическое состояние почвенного покрова в пределах крупного промышленного центра. Полученные данные дополнили имеющиеся представления о влиянии процессов антропогенеза на экологическое состояние почвы на урбанизированных территориях и могут служить основой для усовершенствования системы контроля загрязнения окружающей среды и принятия архитектурно-планировочных решений в соответствии с выявленной пространственной структурой распределения поллютантов.

\section{Библиографический список}

1. Агаркова М.Г., Целищева Л.К., Строганова М.Н. Морфолого-генетические особенности городских почв и их систематика // Вестник МГУ. Сер. 17. Почвоведение. - № 2. - 1991. - С. 11-16.

2. Коротаев Н.Я. Почвы Пермской области. - Пермь: Кн. изд-во, 1962. - 278 с.

3. МУ 2.1.7.730-99 Гигиеническая оценка качества почвы населенных мест.

4. РД 52.18. 286-91. Методика выполнения измерений массовой доли водорастворимых форм металлов (меди, свинца, цинка, никеля, кобальта, хрома, марганца) в пробах почвы атомноабсорбционным анализом: метод. указания. - М., 1991. - 35 с.

5. РД 52.18. 191-891. Методика выполнения измерений массовой доли кислоторастворимых форм: металлов (меди, свинца, цинка, никеля, кадмия) в пробах почвы атомно-абсорбционным анализом. / метод. Указания. - М.: Государственный комитет СССР по Гидрометеорологии, 1990. - 32 с.

6. Ревич Б.А., Сает Ю.Е., Смирнова Р.С., Сорокина Е.П. Методические рекомендации по геохимической оценке загрязнения территорий городов химическими элементами. - М.: ИМГРЭ, 1982. - 111 c.

7. Строганова М.Н., Агаркова А.Д. Городские почвы: опыт изучения и систематики (на примере почв Юго-Западной части г. Москвы) // Почвоведение. - 1992. - № 7. - С. 16-23.

8. Шишкин М.А., Лаптева А.К. Эколого-геохимический анализ современных ландшафтов Прикамья. Екатеринбург, 2009. - 286 с. 


\title{
ECOLOGICAL AND GEOCHEMICAL ASSESSMENT OF THE SOIL IN PERM
}

\author{
M.A. Shishkin, V.A. Gusev, N.P. Sherstobitova \\ Institute of Ecology and Genetics of Microorganisms UB RAS
}

Based on the results of environmental and analytical studies, the level of chemical pollution of urban soils with trace elements of 1, 2, and 3 hazard classes and organic toxicants was assessed. Spatial mapping of ecological condition of the residential zone soils in Perm was performed, the allocation of anomalous sites being indicated.

Keywords: soil, chemical pollution, metal pollutants, ecotoxicants, ecological state, mapping.

\section{Сведения об авторах}

Шишкин Михаил Андреевич, кандидат геолого-минералогических наук, руководитель группы физико-химических исследований, Институт экологии и генетики микроорганизмов УрО РАН - филиал Пермского федерального исследовательского центра УрО РАН (ИЭГМ УрО РАН), 614081, г. Пермь, ул. Голева, 13; e-mail: sma@iegm.ru

Гусев Владимир Анатольевич, ведущий инженер группы физико-химических исследований, ИЭГМ УpO PAH; e-mail: gv@iegm.ru

Шерстобитова Наталья Петровна, старший инженер группы физико-химических исследований, ИЭГМ УрО РАН; e-mail: shnp@iegm.ru 